\title{
Longevity and reproduction period of africanized queen bees in the Northeast region of Brazil
}

\author{
[Longevidade e período de reprodução de abelhas rainhas africanizadas em região do Nordeste \\ Brasileiro]
}

\section{"Artigo Científico/Scientific Article"}

\author{
Renata Valéria Regis de Sousa Gomes ${ }^{1 *}$, Kátia Peres Gramacho ${ }^{2}$, Lionel Segui Gonçalves ${ }^{2}$ \\ ${ }^{1}$ Departamento de Zootecnia, Universidade Federal Rural de Pernambuco (UFRPE), Recife-PE, Brasil. \\ ${ }^{2}$ Centro Tecnológico de Apicultura e Meliponicultura do Rio Grande do Norte (CETAPIS), Universidade Federal Rural \\ do Semi-árido (UFERSA), Mossoró-RN, Brasil. \\ *Autor para correspondência/Corresponding author: E-mail: renatav_sousa@ hotmail.com
}

\begin{abstract}
This study aimed to evaluate the longevity and reproductive period of Africanized queen bees under the climatic conditions of the Zona da Mata region in the state of Pernambuco, Northeast of Brazil. Longevity and reproduction data of 41 Apis mellifera L. queen bees naturally fertilized were collected every 15 days from February 2014 to December 2015, and correlated with climatological data-precipitation, temperature, and relative humidity - from this period. The mean longevity of the queen bees was $6.4 \pm 2.9$ months. The months with the lowest number of death of queens were those with the highest precipitation-May to August-in the study region, presenting a strong negative correlation $(\mathrm{r}=-0.65$ and $p=0.02)$ between the time of queen death and precipitation index. The peak of the reproductive season in this region was September to December. All queen bees laid eggs during all months of the year. The oviposition intensity of the queens and the number of brood combs increased as the temperature increased and the humidity and precipitation index decreased. A colony of Africanized bees replaces their queen at least once a year in the Zona da Mata region. Therefore, it is recommended a constant inspection of the colonies regarding the presence of the queen bee, and the introduction of a new queen when it is absent, if possible with a selected one to be naturally fertilized and, thus, provide a good population for the colony in the peak of the reproductive season in this region-September to December.
\end{abstract}

Keywords: Apis mellifera L; apiculture; queen cell.

\section{Resumo}

O objetivo dessa pesquisa foi avaliar a longevidade e o período reprodutivo de abelhas rainhas africanizadas nas condições climáticas da região da zona da mata de Pernambuco, no Nordeste do Brasil. Os dados de longevidade e reprodução de 41 rainhas de abelhas Apis mellifera L. fecundadas naturalmente foram registrados quinzenalmente e correlacionados com dados de condições climáticas (índice pluviométrico, temperatura, umidade relativa) no período de fevereiro de 2014 a dezembro de 2015. A longevidade média das rainhas foi $6.4 \pm 2.9$ meses. Os meses que apresentaram o menor número de morte de rainhas foram os meses com maior volume de chuvas (que correspondem aos meses de maio a agosto na região), apresentando uma forte correlação negativa $(r=-0.65$ e $p=0.02)$ entre morte da rainha e o índice pluviométrico. A época de pico reprodutivo foi entre os meses de setembro a dezembro. Todas as rainhas realizaram postura durante todos os meses do ano. A intensidade de ovoposição e o número de quadros com crias aumentaram à medida que aumentava a temperatura e diminuía a umidade relativa e a pluviosidade. Uma colônia de abelhas africanizadas substitui sua rainha pelo menos uma vez ao ano na região da zona da mata. Recomenda-se, portanto, uma inspeção constante das colônias quanto à presença de rainha e, quando órfãs, a introdução de rainhas novas se possível selecionadas, para serem fecundadas naturalmente, a fim de garantir uma colônia com uma boa população no período de pico reprodutivo, que nessa região é de setembro a dezembro.

Palavras-chave: Apis mellifera L; apicultura; realeiras. 


\section{Introduction}

Queen bees are essential for the health and productivity of the colonies; thus, they are important for the success of apiculture, and several management techniques focus on maximizing their reproductive potential (Tarpy et al., 2012).

The reproductive capacity of a queen bee is directly related to its lifetime, since as the semen reserves run out, the colony begins the selection process to replace the queen bee (Winston, 1987). This denotes a positive relationship between reproduction and longevity. In this sense, queen bees that cannot maintain a good oviposition in the nest are often prematurely substituted, which causes production losses, since the honey production is strongly correlated with the total population of the colony (Woyke, 1971; 1984).

Evaluate the longevity of the queen bee is important, since it affects its quality regarding its potential for sperm stock (Cobey, 2007) through the polyandry, which increases the intra-colony genetic diversity, and confers numerous benefits for the health and productivity of the colony (Tarpy et al., 2011). The body weight at emergency is an important factor for the longevity of the queen bee (Winston, 1987). A heavier queen bee at emergence has a greater capacity to store sperm (Woyke, 1971; Corbella and Gonçalves, 1982). This phenotypic characteristic is a reliable indicator for breeding programs and performance of the colony aiming to obtain good-quality queen bees (Souza et al., 2013; Camargo et al., 2015).

The bees' lifetime is also affected by their regional climatic conditions (Szabo, 1993). In tropical climate conditions, which have high temperatures, queen bees have a continuous oviposition throughout the year, with intensity varying according to the availability of nectar and pollen, which determines the longevity of the queen bee (Silva et al., 1991), making it necessary an annual exchange of the old queen by a young and selected queen bee (Martinez and Soares, 2012). The understanding the biological cycle, colony development, and environmental conditions of places where apiculture is practiced is necessary, since this determines the favorable months for the production and exchange of queen bees in the apiaries (Carbonari et al., 2016) and promotes a more effective management and predictability by the beekeeper.
In Brazil, studies on the longevity of queen bees were carried out in the Southeast and South regions (Silva et al., 1991; Toledo et al., 2012; Souza et al., 2013), however, studies on the Northeast region on this subject is scarce. This region is divided in sub-regions, such as Zona da Mata, Agreste and Sertão, which present different climate conditions. Although the impact of these environmental changes on bees is not fully known, studies indicate that environmental changes have a direct effect on the development of honeybee colonies (Le Conte and Navajas, 2008).

Considering that the lifetime and development of a bee colony depends especially on the region, climatic conditions and forage availability, the objective of this work was to evaluate the longevity and reproductive period of Africanized queen bees under the climatic conditions of the Zona da Mata region in the state of Pernambuco, Northeast of Brazil.

\section{Material and Methods}

This research was carried out using experimental apiaries of the Department of Animal Science of the Federal Rural University of Pernambuco located in a remnant of Atlantic Forest in Recife, capital of the state of Pernambuco, in the Northeast region of Brazil. Recife is in the coast region, in Zona da Mata physiographic microregion, which has a humid tropical climate characterized by only two seasons, winter-a rainy season from May to August, with average temperature of $24^{\circ} \mathrm{C}$ and average precipitation of $725 \mathrm{~mm}$ - and summer - a hotter season with average temperature of $27^{\circ} \mathrm{C}$ and an average precipitation of $515 \mathrm{~mm}$ (PERNAMBUCO, 2016).

Forty-one virgin Africanized polyhybrid queen bees were introduced into orphaned colonies housed in Langstroth beehives, and naturally fertilized by wild drones. The queen bees were marked with non-toxic white paint on the upper thorax and the evaluations were conducted every 15 days from February 2014 to December 2015. Twenty-four queen bees born in 2014 and 17 in 2015. The mean longevity of the queen bees was evaluated by recording the time from the beginning of their oviposition to their death in the hives. The number of brood combs from each colony was 
counted to evaluate the queen bee's oviposition activity over the months; and the number of queen cells constructed naturally over the months was counted to estimate the reproduction period of the colonies, and evaluate the peak of the reproductive season in the studied region. The queen cells were destroyed to control swarming.

The monthly average of precipitation, humidity, and temperature data were obtained from the Pernambuco State Water and Climate Agency (Apac Recife, Várzea, Code 30) and the National Meteorological Institute (Imet Recife, Automatic weather station A301) (BRASIL, 2016; PERNAMBUCO, 2016).

The means and standard deviation of these variables were evaluated. The Pearson correlation coefficient was used to analyze the correlation between the climatic variables (precipitation, humidity, and temperature) and the months of the year, which were independent variables; and the death of queen bees, average number of brood combs, and presence of queen cells were the dependent variables. The regression model that best fitted the data of number of brood combs in the months of the year was $Y=\beta_{0}+\beta_{1} X+\beta_{2} X^{2}$; and the one that best fitted the data of number of queen cells was $Y=\beta_{0}+$ $\beta_{1} X+\beta_{2} X^{2}+\beta_{3} X^{3}$. All analyses were carried out using a significance level of 5\%, and the Tukey test was used to compare the means.

\section{Results and Discussion}

Three out of the 41 Africanized queen bees lived 12 months, and one queen bee died one month after emergence, under the climatic conditions of Recife, Pernambuco, Brazil, presenting a mean longevity of $6.4 \pm 2.9$ months (Figure 1).

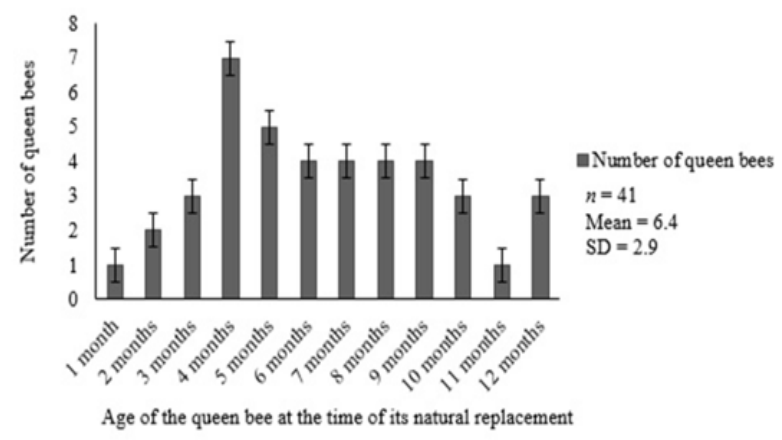

Figure 1. Mean longevity of Africanized queen bees in hives of the DZ/UFRPE experimental apiary from February 2014 to December 2015.
Studies conducted in the Southeast region, in Ribeirão Preto SP, with Africanized queen bees classified into two groups by weight- $<180 \mathrm{mg}$ and $>200 \mathrm{mg}$ - showed that heavier queen bees have twice the longevity (mean of 19 months) of the lighter ones (mean of 9 months) (Souza et al., 2013). Although, these data are from single papers, they denote the importance of using heavier queen bees for a greater longevity compared to those obtained in a regular transfer and hardly presenting more than $200 \mathrm{mg}$.

Toledo et al. (2012) evaluated Africanized queen bees in the South region of Brazil, during two periods (March 1981 to September 1983, and April 1989 to August 1990), and found differences in their life span, with longevities of $9.0 \pm 4.9$ and 4.6 \pm 2.0 months, and the environmental conditions presenting strongly effect on the performance of individuals in the colony (Toledo et al., 2010).

The low longevity of Africanized queen bees in Brazil is also due to their continuous breeding during practically all year, with no diapause, however, there is a reduction in the oviposition in the period of food scarcity (Silva et al., 1991). This increases the aging of the queen bee, thus, the annual replacement of queen bees to improve the average productivity of apiaries is recommended.

The results of the correlation between queen bee death and climatic variables showed a significant negative correlation between the queen bee death and the precipitation index $(r=-0.65$ and $p=0.02)$, and non-significant correlation with temperature $(r=0.38$ and $p=0.21)$ and relative humidity $(r=-0.55$ and $p=0.06$ ) (Table 1$)$.

The months that presented the highest precipitation-May to August - were the ones with the lowest number of queen bee deaths in the region evaluated (Figure 2). According to Le Conte and Navajas (2008), Apis mellifera bees present great adaptive potential regarding climate, which directly affects their development. This shows that this specie has genetic plasticity and variability, generating selection by development cycles that adequate it to the new environmental conditions. This adaptability is evidenced by the longevity variability of Africanized queen bees in the different regions of Brazil. 
Table 1. Correlation between queen bee death and climatic variables in hives of the DZ/UFRPE experimental apiary.

\begin{tabular}{ccccc}
\hline Months & Death of queen bee & Precipitation $\mathbf{~ m m}$ & Temperature $^{\mathbf{~}} \mathbf{C}$ & Humidity $\%$ \\
\hline Jan & 0 & 85,5 & 26,4 & 69,6 \\
Feb & 4 & 102,5 & 26,8 & 68,6 \\
Mar & 2 & 296,7 & 26,5 & 74,1 \\
Apr & 7 & 171,4 & 26,6 & 71,4 \\
May & 1 & 241,8 & 25,6 & 73,5 \\
Jun & 1 & 384,7 & 24,7 & 77,7 \\
Jul & 1 & 362 & 24,1 & 77,1 \\
Aug & 3 & 139,5 & 23,9 & 74,3 \\
Sep & 8 & 139,9 & 25 & 72,1 \\
Oct & 3 & 81,4 & 25,8 & 71,7 \\
Nov & 2 & 43,3 & 26,4 & 69,3 \\
Dec & 9 & 68,6 & 26,7 & 70,5 \\
\hline \multicolumn{5}{r}{} \\
\hline & Death of queen bee x Precipitation & -0.65 & $\boldsymbol{p}$ & \\
& Death of queen bee x Temperature & 0.38 & $0.02^{*}$ & \\
& Death of queen bee x Humidity & -0.55 & $0.21^{\mathrm{ns}}$ & \\
\hline
\end{tabular}

"Significant $\mathrm{p}<0,05 ;{ }^{\text {ns } N o n-s i g n i f i c a n t ~} \mathrm{p}<0,05$.

The data on the death or replacement of queen bees over the 2014 and 2015 years showed that the months with the highest percentage of natural replacement of queen bees were February, April, September, and December, and these four months accounted for $63.5 \%$ of the queen bee deaths (Figure 2). The time of exiting of a secondary swarm, i.e., the process of reproduction of the colony or natural division of the colony, is related to the replacement of the queen bee; this process is similar in European and African honeybee colonies (Gilley and Tarpy, 2005).

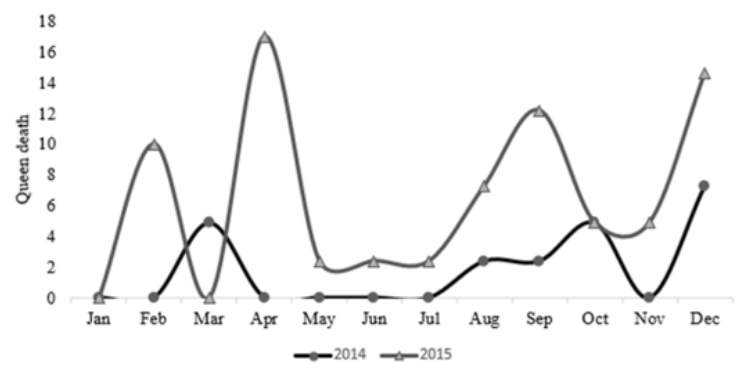

Figure 2. Death of queen bees (\%) in hives of the DZ/UFRPE experimental apiary from February 2014 to December 2015.

According to the number of queen cells recorded throughout the experimental period (431), the queen cells and months of the year presented a significantly positive correlation $(r=0.7$ and $p=$ 0.05 ), with increases in queen cells in September to December (Figure 3). A trend of increasing the frequency of queen cells in September to December was found with $91 \%$ accuracy $\left(R^{2}=0.91\right.$ $>p$-value $=0.0002 ; \mathrm{CV}=32.74)$. These months accounted for $63.8 \%$ of the total number of queen cells registered, whereas in January to August, the queen cells had a low frequency, representing $36.2 \%$ of the total. These data denote that the swarming period in Recife is in September to December.

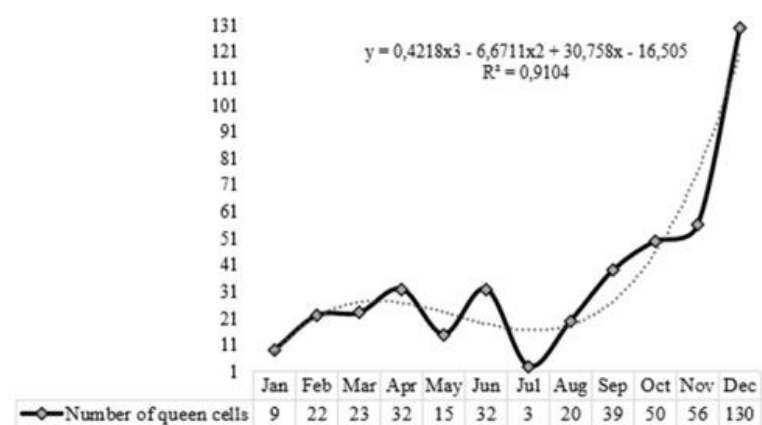

Figure 3. Queen cells found in hives of the DZ/UFRPE experimental apiary from February 2014 to December 2015. Dashed line represents the estimated trend of the frequency of queen cells in the months of the year.

The number of queen cells showed no significant correlation with the number of brood combs in the hives $(r=0.4$ and $p=0.20)$, temperature $(r=0.38$ and $p=0.22)$, precipitation index $(r=-0.46$ and $p=0.12)$, and relative humidity $(r=-0.34$ and $p=0.27)$. Although the peak of production of queen cells occurred in September to December, queen cells were found in all months of the year, and they were not affected by the size of the colony population or climatic variables. Toledo et al. (2012) evaluated colonies of Africanized bees in the South region of Brazil and also found production of queen cells regardless of the colony status, population, presence of the 
queen bee, and food; and that the presence of queen bee in the colony does not inhibit the construction of queen cells, both in times of abundance of food, and of scarcity.

The number of brood combs presented significant positive correlation with the months of the year $\left(\mathrm{R}^{2}=0.51>p\right.$-value $\left.=0.04 ; \mathrm{CV}=15.40\right)$, and temperature $(r=0.79$ and $p=0.0021)$; and a significant negative correlation with relative humidity $(r=-0.77$ and $p=0.0034)$ and the precipitation index $(r=-0.66$ and $p=0.01)$. The annual variation in brood combs showed an increase from September, and a decreasing from April. The period of less activity of the queen bee with oviposition was May to August, which comprises the rainy months (Figure 4). The intensity of oviposition of the queen bee, under the climatic conditions of Recife, increased with increasing temperature and decreasing humidity and, consequently, the number of brood combs increased; but, the number of brood combs had a significant decrease in the rainy season-May to August.

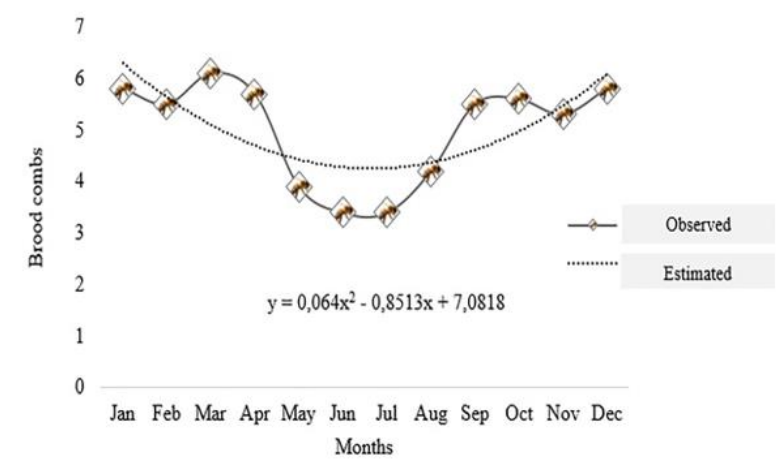

Figure 4. Monthly means of brood combs observed from February 2014 to December 2015, and mean values estimated by the regression model.

Therefore, the information about the longevity and reproductive period of queen bees in a region is important to make the necessary adjustments in the management and production of queen bees, and increase the productivity of apiaries.

A colony of Africanized bees replaces its queen bee at least once a year. Therefore, it is recommended a constant inspection of the colonies regarding the presence of the queen bee, and the introduction of a new queen bee when it is absent, if possible with a selected queen bee, to be naturally fertilized. Hives must be installed in shady places and with available drinking water to generate a colony with good population in the peak of the reproductive season.

\section{Conclusion}

The mean longevity of queen bees under the climatic conditions of the Zona da Mata region in the state of Pernambuco, Brazil, is around six and a half months, with peak of the reproductive season September to December in the evaluated region.

\section{Conflict of interests}

Authors declare no conflict of interests.

\section{References}

BRASIL. Ministério da Agricultura, Pecuária e Abastecimento. Instituto Nacional de Meteorologia - Inmet. Estações e Dados. Disponível em: <www.inmet.gov.br> Acesso em: 26 jan. 2016.

Camargo, S.C.; Lima, E.G.; Toledo, V.A.A.; Garcia, R.C. Abelha rainha Apis mellifera e a produtividade da colônia. Scientia Agraria Paranaensis, 14(4): 213-220, 2015.

Carbonari, V.; Malaspina, O.; Alves Júnior, V.V.; Polatto, L.P. Variation in honey yield per hive of Africanized bees depending on the introducing time of young queens. Ciência Rural, 46(5): 895-900, 2016.

Cobey, S.W. Comparison studies of instrumentally inseminated and naturally mated honey bee queens and factors affecting their performance. Apidologie, 38(4): 390-410, 2007.

Corbella, E.; Gonçalves, L.S. Relationship between weight at emergence, number of ovarioles, and spermathecal volume of africanized honeybees queens Apis mellifera L. Brazilian Journal of Genetics, 5(1): 835-840, 1982.

Gilley, D.C.; Tarpy, D.R. Three mechanisms of queen elimination in swarming honey bee colonies. Apidologie, 36(3): 461-474, 2005.

Le Conte, Y.; Navajas, M. Climate change: impact on honey bee populations and diseases. Revue Scientifique et Technique (International Office of Epizootics), 27(2): 499-510, 2008.

Martinez, O.A.; Soares, A.E.E. Melhoramento genético na apicultura comercial para produção da própolis. Revista Brasileira de Saúde e Produção Animal, 13(4): 982-990, 2012.

PERNAMBUCO. Agência Pernambucana de Águas e Clima - (Apac). Meteorologia. Disponível em: < http://www.apac.pe.gov.br/meteorologia/esta coes-do-ano.php?> Acesso em: 26 jan. 2016. 
Silva, E.C.A.; Alves, M.L.T.M.F.; Silva, R.M.B.; Moreti, A.C.C.C. Longevidade de rainhas de abelhas africanas neotropicais (Apis mellifera L.). Boletim de Indústria Animal, 48(1): 5762, 1991.

Souza, D.A.; Bezerra-Laure, M.A.; Francoy, T.M.; Gonçalves, L.S. Experimental evaluation of the reproductive quality of Africanized queen bees (Apis mellifera) on the basis of body weight at emergence. Genetics and Molecular Research, 12(4): 5382-5391, 2013.

Szabo, T.I. Length of life of queens in honey bee colonies. Journal of Apicultural Research, 133(10): 723-724, 1993.

Tarpy, D.R.; Keller, J.J.; Caren, J.R.; Delaney, D.A. Experimentally induced variation in the physical reproductive potential and mating success in honey bee queens. Insectes Sociaux, 58(4): 569-574, 2011.

Tarpy, D.R.; Keller, J.J.; Caren, J.R.; Delaney, D.A. Assessing the Mating "Health" of Commercial Honey Bee Queens. Journal of Economic Entomology, 105(1): 20-25, 2012.

Toledo, V.A.A.T.; Neves, C.A.; Alves, E.M.; Oliveira, J.R.; Ruvolo-Takasusuki, M.C.C.;
Fraquinello, P. Produção de geleia real em colônias de abelhas africanizadas considerando diferentes suplementos proteicos e a influência de fatores ambientais. Acta Scientiarum. Animal Sciences, 32(1): 93-100, 2010.

Toledo, V.A.A.; Nogueira-Couto, R.H.; Malheiros, E.B.; Fraquinello, P.; Sereia, M.J. Produção de realeiras em colônias híbridas de Apis mellifera L. e longevidade de rainhas. Global Science and Technology, 5(2): 176-185, 2012.

Winston, M.L. The biology of the honeybee. Cambridge: Harvard University Press, 1987. $281 \mathrm{p}$.

Woyke, J. Correlations between the age at which honeybee brood was grafted, characteristics of the resultant queens and results of insemination. Journal of Apicultural Research, 10(1): 45-55, 1971.

Woyke, J. Correlations and interactions between population, length of worker life and honey production by honey bees in a temperate region. Journal of Apicultural Research, 23(3): 148-156, 1984. 